\title{
Relationship between insulin-mediated glucose disposal and regulation of plasma and adipose tissue lipoprotein lipase
}

\author{
P. M aheux ${ }^{1}$, S.A zhar' ${ }^{1}$, P. A .Kern' ${ }^{2}$, Y.-D.I.C hen ${ }^{1}$, G . M . R eaven ${ }^{1}$ \\ ${ }^{1}$ Department of Medicine, Stanford University School of Medicine and Geriatric Research, Education and Clinical Center, \\ VA Palo Alto Health Care System, Palo Alto, California, USA \\ ${ }^{2}$ Research Service, John L. McClellan Memorial Veterans Hospital, Little Rock, Arkansas, USA
}

Summary The relationship between insulin-mediated glucose disposal and fasting insulin and triglyceride (TG) concentrations, plasma post-heparin lipoprotein lipase (PH-LPL) activity and mass, and adipose tissue LPL activity, mass, and mRNA content was defined in 19 non-diabetic men. Insulin-mediated glucose uptake [as assessed by determining the steady-state plasma glucose (SSPG) concentration during a continuous infusion of somatostatin, insulin, and glucose] was significantly correlated with fasting TG concentration $(r=0.54, p<0.02)$, plasma PH-LPL activity $(r=-0.52, p<0.03)$ and mass $(r=-0.49, p<0.03)$, and adipose tissue LPL mRNA content $(r=-0.68$, $p<0.001)$. Comparable relationships were also seen when fasting insulin concentration was substituted for SSPG. Although adipose tissue LPL and mass correlated with each other $(r=0.76, p<0.001)$ in a fasting state, they were not related to any other variable measured. Using in vivo and molecular biology techniques, these data demonstrate that the more insulin resistant an individual, the lower the level of plasma PH-LPL activity and mass, and the higher the plasma TG concentration. Since lower concentrations of adipose tissue mRNA were also directly correlated with plasma PH-LPL mass $(r=0.57, p<0.01)$, and inversely with plasma TG concentration $(r=-0.68$, $p<0.001)$ as well as SSPG $(r=-0.68, p<0.001)$, it can be postulated that the relationship between insulin resistance and LPL activity and plasma TG concentration is associated with the inability of insulin to stimulate the transcription or to increase the intracellular mRNA stability of adipose tissue LPL in insulin resistant individuals. [Diabetologia (1997) 40: 850-858]

Keywords Lipoprotein lipase, insulin resistance, adipose tissue, RNA messenger, triglycerides.
Lipoprotein lipase plays a key role in the catabolism of triglyceride(TG)-rich lipoproteins [1], and it is generally accepted that the activity of this enzyme is decreased in insulin-deficient states [2-4]. While alterations in LPL have long been suspected in insulin resistance $[1,5]$, the situation concerning the

Received: 10 December 1996 and in final revised form: 8 April 1997

Corresponding author: P. Maheux, M.D., Division of Endocrinology and Metabolism, Centre Universitaire de Santé de l'Estrie (Pavillon Fleurimont), 3001 12th Avenue North, Sherbrooke, Québec, Canada J1H 5N4

A bbreviations: LPL, lipoprotein lipase; PH-LPL, post-heparin lipoprotein lipase; SSPG, steady-state plasma glucose; TG, triglycerides; AT, adipose tissue. relationship between LPL and insulin-mediated glucose disposal is more complicated. Patients with non-insulin-dependent diabetes mellitus are generally assumed to be insulin resistant $[6,7]$, and there is evidence that LPL activity is decreased in these subjects [8, 9]. However, this conclusion is confounded by not knowing whether the changes noted are due to the insulin resistance, the decrease in plasma insulin concentration or the ambient hyperglycaemia that is also present in these individuals. One approach to evaluating the effect of insulin resistance per se on LPL activity, is to study normal glucose tolerant individuals. Results of recent studies have shown that LPL activity was reduced in post-heparin (PH) plasma [10, 11], skeletal muscle $[12,13]$ and adipose tissue $[14,15]$ of insulin resistant individuals. To our knowledge, however, adipose tissue LPL activity, 
immunoreactive mass and mRNA levels have never been measured simultaneously in such individuals. Our hypothesis is that insulin resistance is associated with hypertriglyceridaemia and that this defect could be due to an impaired clearance of TG-rich particles by a decrease in adipose tissue LPL. The present study was initiated to address this issue, and we believe that it represents the first attempt to define the relationship between variations in insulin sensitivity, plasma PH-LPL activity and immunoreactive mass, adipose tissue LPL activity and immunoreactive mass, and adipose tissue LPL mRNA content.

\section{Subjects and methods}

Study population. Nineteen non-diabetic male volunteers were recruited for this study. They were in good general health, not taking any medication known to affect glucose or lipoprotein metabolism, and non-diabetic by conventional criteria [16]. Of these, only one volunteer had a blood pressure in the high range $(161 / 90 \mathrm{~mm} \mathrm{Hg})$. The study was approved by Stanford University Human Subjects Committee, and each individual gave written consent upon admission to the General Clinical Research Center.

$M$ etabolic evaluation. Each volunteer was studied on three different occasions, always after a $12 \mathrm{~h}$ overnight fast, at which time blood was obtained for measurement of fasting plasma insulin [17], and TG [18] concentrations. Studies were performed in random order, over a period of 1 month and at least 3 days apart. On one morning, resistance to insulin-mediated glucose disposal was quantified by the insulin suppression test as described previously [19]. Briefly, steady-state plasma insulin and glucose (SSPG) concentrations were measured at $10 \mathrm{~min}$ intervals during the last $30 \mathrm{~min}$ of a $180 \mathrm{~min}$ infusion of somatostatin $(350 \mu \mathrm{g} / \mathrm{h})$, insulin $\left(25 \mathrm{mU} \cdot \mathrm{m}^{-2} \cdot \mathrm{min}^{-1}\right)$, and glucose $\left(1.33 \mathrm{mmol} \cdot \mathrm{m}^{-2} \cdot \mathrm{min}^{-1}\right)$. Since steady-state plasma insulin concentrations were similar in all individuals, the higher the SSPG concentration, the more insulin resistant the individual.

M easurement of plasma and tissue L PL activity On a separate day, blood samples were obtained 30 min after an intravenous bolus injection of 100 units $/ \mathrm{kg}$ of heparin [20] for determination of PH-LPL activity and its immunoreactive mass. Blood samples were kept on ice, plasma separated immediately, quick frozen in a dry-ice ethanol bath, and stored at $-80^{\circ} \mathrm{C}$ until assayed in batches. Finally, approximately $0.5 \mathrm{~g}$ of subcutaneous adipose tissue was obtained under local anesthaesia by open biopsy from the lower abdominal wall on a third morning. This sample was rapidly frozen between two blocks of dry ice, and kept at $-80^{\circ} \mathrm{C}$ until analysed, within 6 months, for tissue LPL activity, immunoreactive mass, and mRNA content. Since the heparin used for the PH-LPL could influence adipose tissue LPL activity, the biopsy was always performed at least 1 week apart.

PH-LPL activity was determined using a sonicated $\left[{ }^{3} \mathrm{H}\right]$-triolein emulsion as substrate, prepared according to NilssonEhle and Schotz [21]. The $\left[{ }^{3} \mathrm{H}\right]$-oleic acid labelled triolein was obtained from Amersham Life Science Inc. (Arlington Heights, Ill., USA). This labelled triolein was not repurified by TLC since the expected LPL activities in adipose tissue extracts and post-heparin plasma were high. To minimize the effect of partial glycerides (monoglycerides, diglycerides) on the
LPL activity assay, blank values were always subtracted. We added 50-100 $\mu \mathrm{l}$ of a six-fold diluted post-heparin plasma to $100 \mu \mathrm{l}$ of substrate in the presence of heat inactivated $\left(62^{\circ} \mathrm{C}\right.$, $10 \mathrm{~min})$ human serum $(10 \%)$ as cofactor for LPL, and incubated it for $30 \mathrm{~min}$ at $37^{\circ} \mathrm{C}$. The $\left[{ }^{3} \mathrm{H}\right]$-oleic acid released was extracted and separated from $\left[{ }^{3} \mathrm{H}\right]$-triolein substrate as described by Belfrage et al. [22], and radioactivity quantified by liquid scintillation spectrometry. In order to distinguish the activity of plasma PH-LPL activity from that of residual hepatic lipase, high salt concentration $(1 \mathrm{~mol} / \mathrm{l} \mathrm{NaCl}$ in presence of human serum) was employed to inhibit LPL and hepatic lipase activities determined in a separate incubation [23]. These values were subtracted from the total lipolytic activity to obtain the $\mathrm{PH}-$ LPL values. The results are expressed as mmol of non-esterified fatty acid (NEFA) released per hour per ml of post-heparin plasma.

Total extractable adipose tissue LPL activity was measured after detergent extraction as described by Iverius and Brunzell [24]. Approximately $150 \mathrm{mg}$ of frozen adipose tissue were homogenized with a polytron in $300 \mu \mathrm{l}$ of extraction buffer ( $0.5 \%$ deoxycholate, $0.2 \mathrm{~mol} / 1$ Tris, $0.25 \mathrm{~mol} / 1$ sucrose, $1 \%$ bovine serum albumin, 10 units $/ \mathrm{ml}$ heparin and $0.02 \%$ NP-40; $\mathrm{pH}$ 8.6) and centrifuged for $15 \mathrm{~min}$. Aliquots of the infranatant below the fatty cake were then diluted 1:15 with detergent free extraction buffer. Similar to the assay of PH-LPL, 100 and $150 \mu \mathrm{l}$ were mixed with $150 \mu \mathrm{l}$ glycerol-stabilized $\left[{ }^{3} \mathrm{H}\right]$-triolein substrate containing heated human serum, and the mixture incubated for $1 \mathrm{~h}$ at $37^{\circ} \mathrm{C}$. To correct for the residual non-LPL lipolytic activities present in the tissue, these activities were determined in a different incubation in which LPL activity was inhibited by $1 \mathrm{~mol} / \mathrm{l} \mathrm{NaCl}$. The results are expressed as $\mu \mathrm{mol}$ of NEFA released per hour per $g$ of frozen tissue.

M easurement of plasma and tissue L PL immunoreactive mass. LPL immunoreactive mass was measured by a non-competitive indirect solid-phase ELISA, using two different polyclonal chicken anti-LPL antibodies, as described previously [25]. This immunoassay has been extensively validated by Kern's group [25-27] and the antibodies used were shown to identify both plasma and tissue LPL by Western blotting and immunoprecipitation. In brief, post-heparin plasma and adipose tissue extracts, prepared as described above, were diluted in a buffer containing $1 \mathrm{~mol} / 1 \mathrm{NaCl}, 0.1 \%$ Triton $\mathrm{X}-100$, and protease inhibitors, and added to a microtitre plate coated with affinity purified anti-LPL antibodies (number $2271,5 \mu \mathrm{l} / \mathrm{ml}$ in $0.1 \mathrm{~mol} / 1$ carbonate buffer, $\mathrm{pH} 9.5$ ). After incubation for $72 \mathrm{~h}$ at $4{ }^{\circ} \mathrm{C}$, the wells were washed and biotinylated second anti-LPL antibodies (number 2272, $0.3 \mu \mathrm{l} / \mathrm{ml}$ ) were added. The colour was developed by addition of streptavidin-horseradish peroxidase and read at $490 \mathrm{~nm}$ using a spectrophotometer. LPL immunoreactive mass was expressed in relation to purified bovine LPL, and data expressed as pmol of immunoreactive LPL/g (for adipose tissue) or nmol/l (for plasma) assuming a molecular weight for LPL of $55 \mathrm{kDa}$. Under the aforementioned conditions, we have previously shown that hepatic lipase and Triton X-100 do not interfere with this ELISA and that serial dilutions of post-heparin plasma are paralleled to a curve for bovine LPL [26, 27]. Various parameters such as $\mathrm{pH}$ of antibodies buffers, incubation time and assay temperature have also been studied previously to obtain maximum sensitivity and accuracy [26]. By repeated measurements of the same frozen LPL sample, intra- and interassay variations were calculated at 5 and $16 \%$, respectively [25]. Finally, it is important to note that this LPL ELISA recognizes dimeric as well as monomeric forms of LPL [26, 27]. The antibodies were indeed shown to recognize inactive LPL under denaturing conditions [27] and to inhibit LPL activity $[25,26]$. 

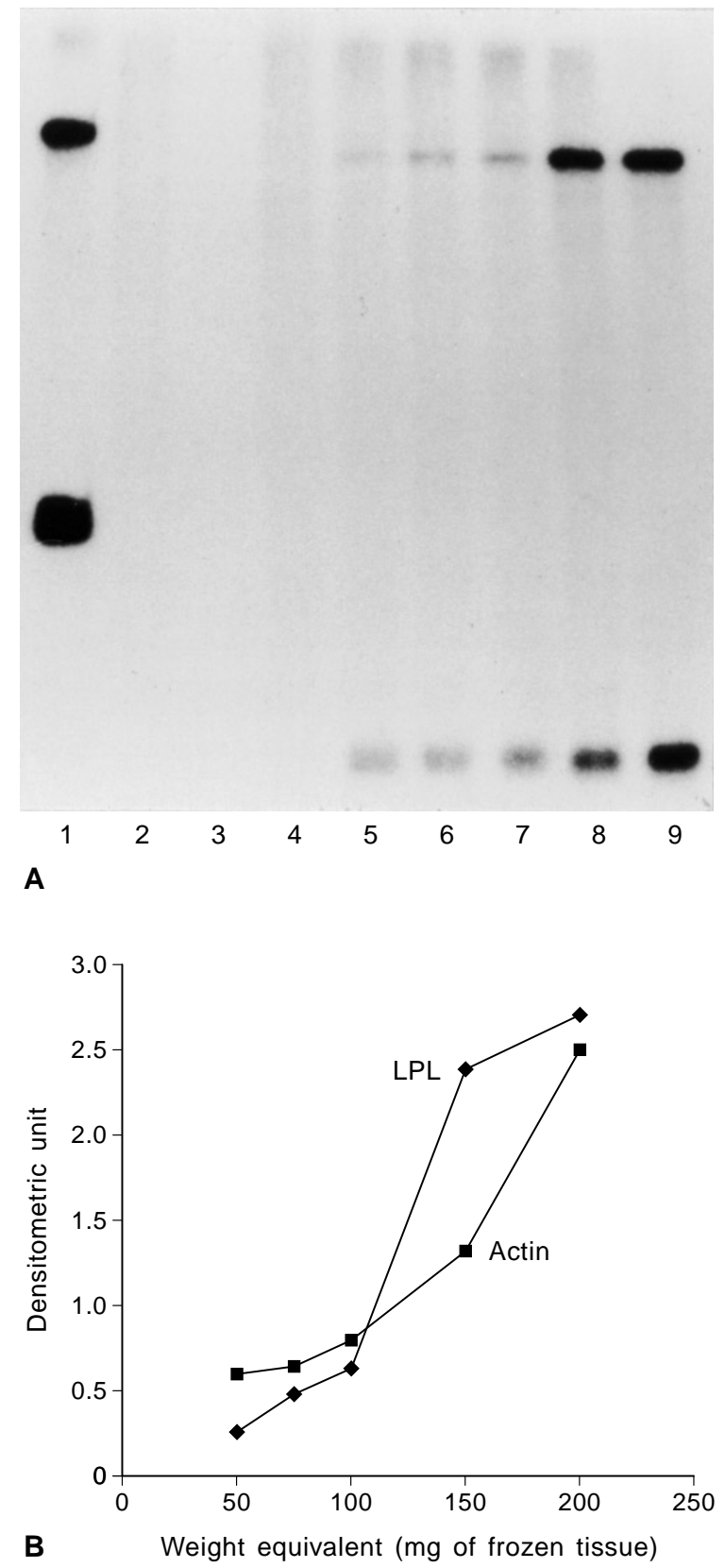

Fig. 1. (A) RNAse protection assay of LPL in human adipose tissue. RNA was extracted from a sample of subcutaneous human adipose tissue and hybridized overnight with excess LPL and $\beta$-actin antisense cRNA probes. Lane 1: Undigested LPL (489 nt) and $\beta$-actin (120 nt) cRNA probes; Lane 2: LPL and $\beta$-actin cRNA probes alone after digestion with RNAse T1/A; Lanes 3 and 4: Control tRNA hybridized with both cRNA probes; Lanes 5 to 9: RNAse protection assay showing protected fragments of LPL (413 nt) and $\beta$-actin (87 nt) with increasing amounts of adipose tissue: 50 (Lane 5), 75 (Lane 6), 100 (Lane 7), 150 (Lane 8) and 200 (Lane 9) mg equivalent of frozen adipose tissue. (B) This graphic demonstrates that with an increasing amount of tissue, there is an increase in intensities of each protected fragments reaching a plateau, for LPL, at about $200 \mathrm{mg}$. Intensity is given in absorbance units at 490 $\mathrm{nm}$ of eluted silver grains from each band
Ribonuclease protection assay. The concentration of human LPL mRNA was determined using a sensitive ribonuclease protection assay [28]. For LPL, a 413 bp fragment (position 440-853) was subcloned into EcoRI-XbaI sites of the pBluescript $\mathrm{KSII}^{+}$from Stratagene La Jolla, Calif., USA). Similarly, an 87 bp PCR generated $\beta$-actin fragment (position 1304-1391; kindly provided by Dr. T. Wu, Stanford University Medical Center) was subcloned in EcoRV sites of pBS KSII ${ }^{+}$. The sequence and orientation of both clones were confirmed by the chain termination procedure as described by Sanger et al. [29]. The plasmids were linearized with appropriate restriction endonucleases and the antisense cRNA probes were synthesized using $\left[{ }^{32} \mathrm{P}\right]$ rCTP and appropriate T7 or T3 RNA polymerase following the method supplied in the Strategene's in vitro transcription kit.

Total cellular RNA from adipose tissue samples was isolated using the acid guanidinium thiocyanate-phenol-chloroform extraction method $[30,31]$. The amount of total RNA recovered was in the range of 2 to $5 \mu \mathrm{g}$ per $100 \mathrm{mg}$ of frozen adipose tissue, in agreement with previously published data [32]. Aliquots of total or control RNA were dried under vacuum and redissolved in $30 \mu \mathrm{l}$ of hybridization buffer containing $10^{5}$ CPM $\left[{ }^{32} \mathrm{P}\right]$-labelled antisense LPL and $\beta$-actin cRNA transcripts [28]. The mixture was incubated for $5 \mathrm{~min}$ at $85^{\circ} \mathrm{C}$ to denature RNA and was then rapidly transferred to hybridization temperature of $42^{\circ} \mathrm{C}$ for overnight incubation (about $18 \mathrm{~h}$ ). To digest unprotected probe, $350 \mu \mathrm{l}$ of ribonuclease digestion buffer $(10 \mathrm{mmol} / \mathrm{l}$ Tris- $\mathrm{HCl}, 5 \mathrm{mmol} / \mathrm{l}$ EDTA, $0.3 \mathrm{~mol} / \mathrm{l} \mathrm{NaCl})$ containing $40 \mu \mathrm{g} / \mathrm{ml}$ ribonuclease A and $2 \mu \mathrm{g} / \mathrm{ml}$ ribonuclease T1 (Ambion, Austin, Texas, USA) was added to the hybridization reaction and incubated $1 \mathrm{~h}$ at $30^{\circ} \mathrm{C}$. The RNAse digestion reaction was terminated by addition of proteinase $\mathrm{K}(50 \mu \mathrm{g})$ and SDS ( $2 \mathrm{mg}$ ) and incubation for $15 \mathrm{~min}$ at $37^{\circ} \mathrm{C}$. After phenol-chloroform extraction, the protected RNA-RNA hybrids were ethanol precipitated using yeast tRNA as a carrier. The pellet was dissolved in $15 \mu \mathrm{l}$ of loading buffer ( $80 \%$ formamide, $1 \mathrm{mmol} / 1$ EDTA, $0.1 \%$ bromophenol blue and $0.1 \% \mathrm{xy}-$ lene cyanol, $\mathrm{pH} 8.0$ ) and heated for $5 \mathrm{~min}$ at $85^{\circ} \mathrm{C}$. The protected fragments were separated on a $6 \%$ acrylamide urea denaturing gel [33]. After electrophoresis, gels were exposed to Kodak XAR-5 film at $-70^{\circ} \mathrm{C}$ with intensifying screens. For strong signals, gels were usually exposed for $6-12 \mathrm{~h}$ and for weaker signals for up to $48 \mathrm{~h}$. To increase detection sensitivity and resolution, LPL and $\beta$-actin mRNA were quantified by eluting the silver grains of film as previously described [34]. The LPL mRNA content was normalized per unit $\beta$-actin and expressed in arbitrary units over $\beta$-actin. Initially, a series of experiments were also performed in which hybridizations were done on a range of input RNA (50, 75, 100, 150 and $200 \mathrm{mg}$ equivalent of frozen adipose tissue), using a constant amount of medium-high specific activity probes. The results of these control studies are shown in Figure $1 \mathrm{~A}$ and $1 \mathrm{~B}$, and it can be seen from these figures that both the LPL and $\beta$-actin mRNAs were expressed abundantly. In addition, the intensity of the respective protected fragments increased with increases in input RNA indicating a molar excess of probes. Although transcription of $\beta$-actin can be influenced by insulin $[35,36]$, this has been studied in vitro with insulin doses that were 40-1000 times the plasma insulin concentrations found in our most insulin resistant volunteer. Thus, we believe that $\beta$-actin represents an appropriate standard under the conditions of our experiments.

Statistical analyses. Data are expressed as mean $\pm \mathrm{SD}$, and the relationship between variables was determined by Pearson correlation coefficient [37] using the Statistical Analysis System (SAS). Where indicated, a multiple regression analysis was also performed. 
Table 1. Subjects' characteristics

\begin{tabular}{|c|c|c|}
\hline Variables & Mean \pm SD & Range \\
\hline Age (years) & $56 \pm 9$ & $33-72$ \\
\hline Body mass index $\left(\mathrm{kg} / \mathrm{m}^{2}\right)$ & $26.5 \pm 3.4$ & $20.8-33.9$ \\
\hline Blood pressure $(\mathrm{mm} \mathrm{Hg})$ & $131 \pm 16 / 77 \pm 9$ & $113 \pm 161 / 61-90$ \\
\hline Fasting glucose $(\mathrm{mmol} / \mathrm{l})$ & $5.3 \pm 0.7$ & $3.7-6.3$ \\
\hline Fasting insulin $(\mathrm{pmol} / \mathrm{l})$ & $60 \pm 33$ & $12-120$ \\
\hline Fasting triglycerides $(\mathrm{mmol} / \mathrm{l})$ & $1.3 \pm 0.6$ & $0.3-2.9$ \\
\hline $\mathrm{SSPG}(\mathrm{mmol} / \mathrm{l})$ & $8.4 \pm 4.3$ & $2.7-15.8$ \\
\hline $\begin{array}{l}\text { PH-LPL activity } \\
\left(\mu \mathrm{mol} \mathrm{NEFA} \cdot \mathrm{h}^{-1} \cdot \mathrm{ml}^{-1}\right)\end{array}$ & $7.8 \pm 3.5$ & $1.5-16.1$ \\
\hline PH-LPL mass (nmol/l) & $1.37 \pm 0.38$ & $0.78-2.34$ \\
\hline $\begin{array}{l}\text { Adipose tissue LPL activity } \\
\left(\mu \mathrm{mol} \text { NEFA } \cdot \mathrm{h}^{-1} \cdot \mathrm{g}_{\text {tissue }}{ }^{-1}\right)\end{array}$ & $2.6 \pm 2.5$ & $0.6-10.7$ \\
\hline $\begin{array}{l}\text { Adipose tissue LPL mass } \\
\text { (pmol/g tissue) }\end{array}$ & $4.78 \pm 2.55$ & $1.10-12.15$ \\
\hline $\begin{array}{l}\text { Adipose tissue LPL mRNA } \\
\text { (arbitrary units over } \beta \text {-actin) }\end{array}$ & $1.80 \pm 0.46$ & $0.82-2.39$ \\
\hline
\end{tabular}

\section{Results}

Table 1 displays the mean \pm SD and range of the variables measured in the 19 males studied. Their ages ranged from 33 to 72 years, and body mass index from 20.8 to $33.9 \mathrm{~kg} / \mathrm{m}^{2}$. They were generally not hypertensive, and had normal glucose tolerance. However, there was an approximate 5-10 fold range of variation in fasting plasma insulin, fasting plasma triglycerides and the degree of insulin resistance (as documented by SSPG values). The activity and mass of both plasma PH-LPL and adipose tissue LPL are also presented, together with the adipose tissue LPL mRNA levels. Although not obvious from these data, it should be recognized that LPL activity per unit mass ( $\mu \mathrm{mol}$ of NEFA released per hour/pmol of immunoreactive LPL mass) is higher in post-heparin plasma than that seen in adipose tissue. This conclusion is based on the following: PH-LPL activity PH-LPL mass is $\sim 5.7 \mu \mathrm{mol}$ NEFA per $\mathrm{h} / \mathrm{pmol}$ of LPL; whereas adipose tissue LPL activity $\div$ adipose tissue LPL mass is $\sim 0.6 \mu \mathrm{mol}$ NEFA per $\mathrm{h} / \mathrm{pmol}$ of LPL. Consequently, LPL specific activity in post-heparin plasma is approximately 10 times the specific activity of adipose tissue in the basal state. In the remainder of this section we will present some salient points of the relationships among these measurements.

As shown in Figure 2, both plasma PH-LPL activity and mass were significantly correlated with fasting plasma TG concentration $(r=-0.51, p<0.03$, and $r=-0.53, p<0.02$, Fig. $2 \mathrm{~A}$ and $\mathrm{B}$, respectively). On the other hand, there was no correlation between TG concentration and either adipose tissue LPL activity or mass (data not shown).

Plasma TG concentration correlated with SSPG concentration $(r=0.54, p<0.02)$, and the results
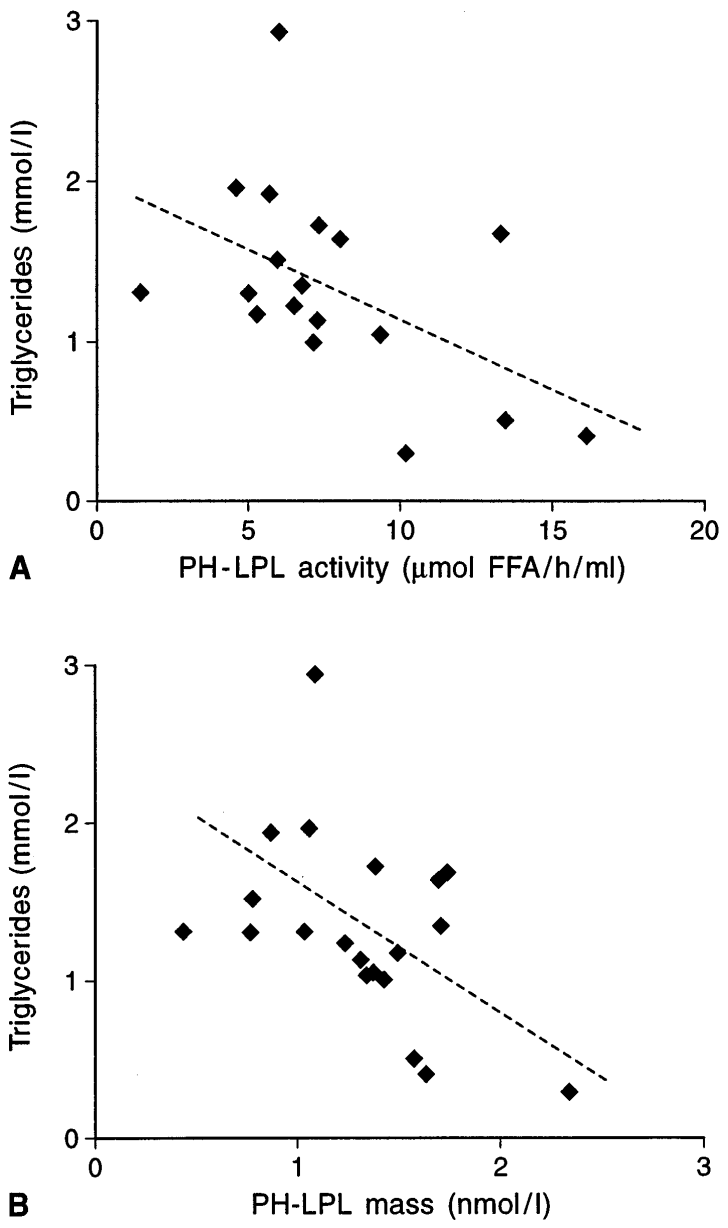

Fig. 2A , B. Relationship between fasting plasma TG concentration and PH-LPL. (A) Plasma TG concentrations are plotted in relation to the subjects' PH-LPL activity; $r=-0.51$, $p<0.03$. (B) Plasma TG concentrations are plotted in relation to the subjects' PH-LPL immunoreactive mass; $r=-0.53$, $p<0.02$

in Figure $3 \mathrm{~A}$ and $\mathrm{B}$ demonstrate that plasma $\mathrm{PH}$ LPL activity $(r=-0.52)$ and immunoreactive mass $(r=-0.49)$ were also significantly correlated to SSPG concentration $(p<0.03)$. Similar, but somewhat weaker correlations were seen between fasting plasma insulin concentration and plasma $\mathrm{PH}$ LPL activity $(r=-0.45, p<0.06)$, and PH-LPL mass $(r=-0.42, p<0.07)$ (data not shown). These data indicate that the more insulin resistant an individual, the less the LPL activity and immunoreactive mass in post-heparin plasma. There was however no relationship between SSPG or fasting plasma insulin concentration and either adipose tissue LPL mass or activity (data not shown).

In contrast to adipose tissue LPL activity and mass, adipose tissue LPL mRNA content correlated highly with plasma TG concentration $(r=-0.68$, $p<0.001$, Fig. 4A). In addition, as can be seen in Figure $4 \mathrm{~B}$, adipose tissue mRNA content also correlated significantly with SSPG concentration $(r=-0.68$, 

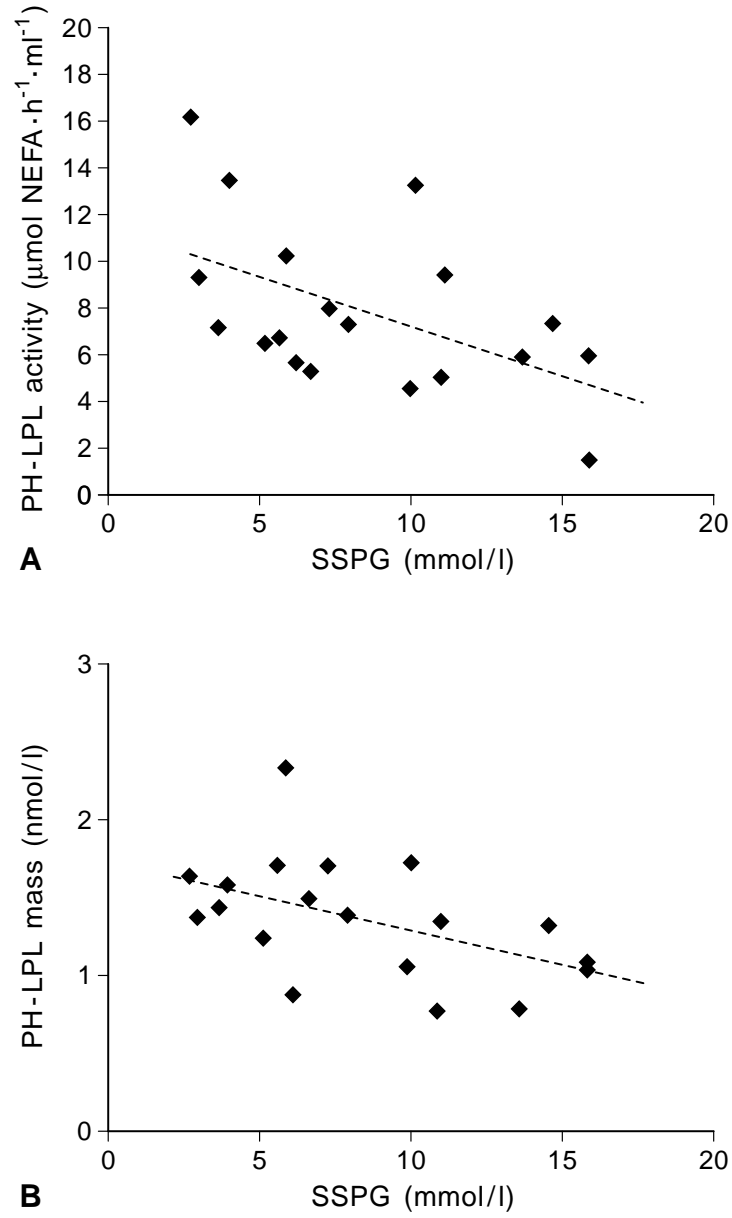

Fig. 3A , B. Relationship between PH-LPL and SSPG, an insulin resistance measurement made with the insulin suppression test. (A) PH-LPL activity plotted in relation to SSPG; $r=$ $-0.52, p<0.03$. (B) PH-LPL mass are plotted in relation to SSPG $; r=-0.49, p<0.03$

$p<0.001)$ and fasting plasma insulin $(r=-0.59$, $p<0.01$, Fig. 4C). A multiple regression analysis was performed in order to see whether there was an independent relationship between insulin resistance (as assessed by SSPG) and adipose tissue LPL mRNA levels. With body mass index, triglycerides and age included in the model, the relationship between adipose tissue LPL mRNA and SSPG was still significant (standardized estimate $=-0.65, p<0.002$ ). Fasting insulin was not included in the model since it is strongly correlated to SSPG. Alternatively, the study population was divided according to their SSPG concentrations, into an insulin resistant $(n=9$, $\mathrm{SSPG}=12.2 \pm 1.0 \mathrm{mmol} / \mathrm{l})$, and an insulin sensitive group $(n=10, \quad S S P G=5.0 \pm 0.5 \mathrm{mmol} / \mathrm{l})$. Steadystate LPL mRNA levels were statistically lower in the insulin resistant subgroup (1.46 \pm 0.14 units over $\beta$-actin) as compared to the insulin-sensitive individuals $(2.10 \pm 0.06$ units over $\beta$-actin; $\mathrm{p}<0.001)$.

Although there was a significant correlation between plasma PH-LPL activity and mass (Fig.5A,
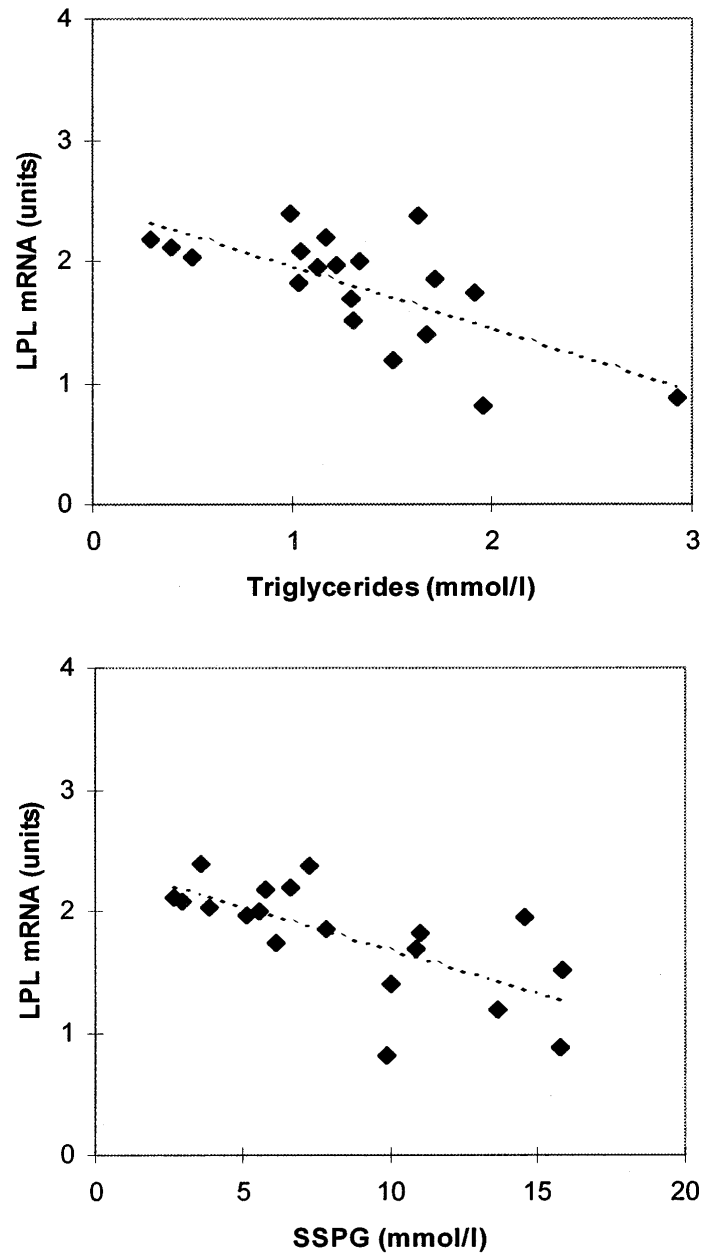

B

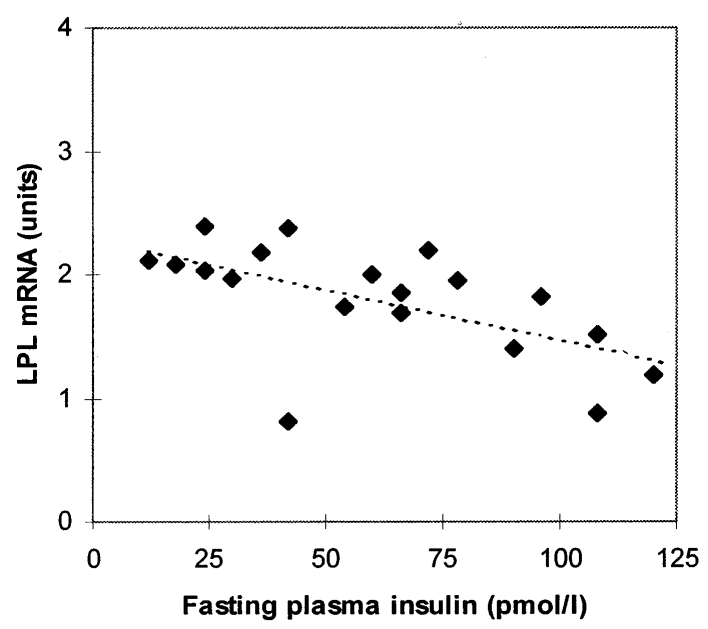

Fig. 4A -C. Relationship between LPL messenger RNA levels in adipose tissue and (A) fasting plasma TG concentration; $r=-0.68, p<0.001$, (B) SSPG; $r=-0.68, p<0.001$, and $(C)$ fasting plasma insulin concentration; $r=-0.59, p<0.01$. LPL mRNA units are arbitrary units calculated from the ratio of the intensities of LPL/ $\beta$-actin protected fragments

$r=0.60, p<0.01)$ and adipose tissue LPL activity and mass (Fig. 5B, $r=0.76, p<0.001$ ), there was no relationship between either plasma PH-LPL activity 

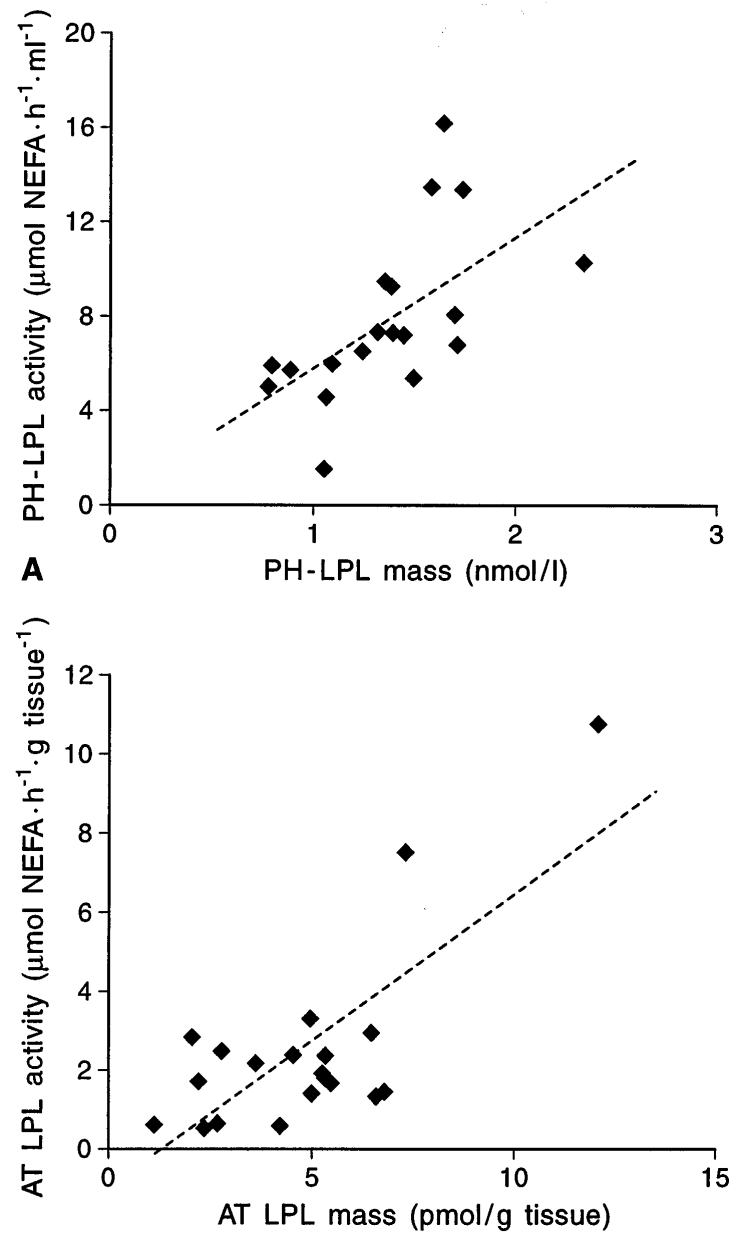

$B$

Fig. 5A , B . Relationship between LPL activity and LPL immunoreactive mass in (A) post-heparin plasma; $r=0.60, p<0.01$, and, (B) in adipose tissue homogenates; $r=0.76, p<0.001$

or mass and adipose tissue LPL activity or mass. Furthermore, adipose tissue LPL mRNA content was not related to tissue LPL activity $(r=-0.31$, $p=0.20)$, immunoreactive mass $(r=-0.26, p=0.29)$, or plasma PH-LPL activity $(r=0.33, p<0.17)$. However, LPL mRNA in adipose tissue was positively correlated with plasma PH-LPL mass $(r=0.57$, $\mathrm{p}<0.01)$.

\section{Discussion}

The results presented demonstrate that the more resistant an individual is to insulin-mediated glucose disposal, the lower will be the plasma PH-LPL activity $(r=-0.52, p<0.03)$ and adipose tissue LPL mRNA levels $(r=-0.68, p<0.001)$. In addition, we have shown for the first time that a similar relationship exists between both plasma PH-LPL immunoreactive mass and the ability of insulin to stimulate glucose disposal $(r=-0.49, p<0.03)$. Thus, it seems reasonable to add a decrease in plasma PH-LPL activity and mass, and adipose tissue LPL mRNA levels to the cluster of abnormalities associated with the insulin resistance syndrome $[6,38]$. The observation that plasma PH-LPL activity and mass were highly correlated $(r=0.60, p<0.01)$, and that both were inversely correlated with fasting plasma TG concentration $(r=-0.51, p<0.03$ and $r=-0.52, p<0.02$, respectively), are reminiscent of the earlier findings by Babirak et al. [39] in patients with familial combined hyperlipidaemia. Of note in this context is the recent observation from our research group that individuals with the form of dyslipidaemia that characterizes familial combined hyperlipidaemia (a high TG and a high LDL-cholesterol) are also insulin resistant [40].

Based upon the relationships we observed between insulin resistance and LPL mRNA in adipose tissue, as well as that seen between plasma PH-LPL activity and mass and LPL mRNA content in adipose tissue, we would offer the following formulation. Insulin acts normally to regulate adipose tissue LPL activity; a notion consistent with previous observations that insulin can stimulate LPL secretion by isolated adipocytes [41, 42], as well as the fact that adipose tissue LPL activity reaches its highest level in the fed state [43] or in response to an insulin infusion [44, 45]. However, as we have recently shown [46], the ability of insulin to inhibit adipose tissue lipolysis is highly correlated with its ability to stimulate insulinmediated glucose disposal by muscle. Thus, it could be speculated that the ability of insulin to modulate LPL mRNA in adipose tissue is defective in insulin resistant subjects, thereby accounting for the fact that the higher the SSPG concentration, the measure of insulin resistance, the lower the adipose tissue LPL mRNA $(r=-0.68, p<0.001)$. Since adipose tissue LPL mRNA content also correlated with plasma PH-LPL mass $(r=0.57, p<0.01)$, it seems reasonable to propose that the relationship between SSPG and plasma PH-LPL mass was secondary to the inability of insulin to stimulate LPL mRNA in adipocytes of insulin resistant individuals. These results are also consistent with the evidence that responsiveness of adipose tissue LPL activity was decreased in obese individuals in proportion to their degree of insulin resistance [14].

In contrast to the relatively straightforward relationships outlined above, was the lack of correlation noted between measures of adipose tissue LPL activity and mass with plasma PH-LPL activity or mass. One should also remember that there was no correlation between adipose tissue LPL mRNA and plasma PH-LPL activity suggesting that adipose tissue might be releasing mainly inactive LPL as suggested by Coppack et al. [47]. Our data show that LPL specific activity was indeed 10 times lower in adipose tissue than in post-heparin plasma. At the simplest level, it is possible that adipose tissue LPL activity and mass have relatively little to do with the amount of LPL 
released into plasma in response to heparin. For example, it is likely that the majority of LPL protein leaves the adipose tissue as it interacts with chylomicrons and/or VLDL [48]. Under these conditions, the mass of LPL present in the adipose tissue at any given time represents the residual LPL pool, and its measurement may provide little, if any, insight as to the functional state of LPL activity. The discrepancy between adipose tissue and post-heparin LPL activity and mass may also be a function of differences in insulin's regulation of LPL in adipose tissue compared to muscle. Pollare et al. [12] have recently noted that adipose tissue LPL was not decreased in obese, hyperinsulinaemic (presumably insulin resistant) individuals, whereas muscle LPL activity was decreased. Our inability to detect a relationship between plasma PH-LPL activity (and mass) and adipose tissue LPL activity (and mass) may therefore simply be a reflection of the fact that muscle is the tissue most affected in insulin resistant individuals. It is also possible that the lack of correlation between adipose tissue LPL and insulin resistance can be explained by the fact that we measured adipose tissue LPL in a fasting state at a time when insulin levels are the lowest. Most reports on the relationship of insulin resistance and adipose tissue LPL have indeed looked at changes in tissue LPL in response to an exogenous insulin infusion [13, 14, 44, 45]. On the other hand, plasma PH-LPL activity (and mass) might represent a contribution from both adipose tissue and muscle. An earlier report by Taskinen et al. [49] showed in non-diabetic individuals, that PH-LPL was closely correlated to LPL activity in both adipose tissue and skeletal muscle. The fact that we only measured total extractable tissue LPL activity and mass might have obscured some important changes in the functional (or heparin-releasable) LPL anchored on the extracellular matrix of adipose tissue. Consequently, it is possible that although measurement of total adipose tissue LPL activity and mass may yield useful information, these values, per se, may provide little knowledge as to the LPL activity in the functional or the plasma compartment. Since the total LPL pool was utilized to measure LPL activity, it is indeed difficult to conclude that the functional LPL was altered in adipose tissue of insulin resistant individuals.

The lack of a relationship between adipose tissue LPL mRNA content and adipose tissue LPL activity and mass is more complicated. The fact that there was a significant correlation between adipose tissue LPL activity and mass suggests that the lack of a relationship was not a simple function of insensitive methodology. In the most general sense, these findings suggest that there could be important post-transcriptional and post-translational mechanisms involved in the regulation of adipose tissue LPL mass and activity in insulin resistance. In this context it is necessary to keep in mind that a decrease in steady-state LPL
mRNA content can result from a decrease in rate of RNA transcription and/or a decrease in cytoplasmic RNA stability. Therefore, steady-state levels of LPL mRNA are not necessarily direct correlates of the number of LPL mRNA molecules transcribed from DNA and/or used by the translational apparatus. For example, if despite lower LPL mRNA levels, the same number of LPL mRNA molecules are translated, LPL mass and activity might not be affected. On the other hand, it is possible that a smaller number of LPL mRNA molecules were translated and that post-translational phenomena might have played an even more important role in maintaining the concentration of mature vs immature LPL proteins and LPL activities in adipose tissue. Post-translational regulatory mechanisms have indeed been well documented in humans as well as in animals $[42,43,50-53]$. These mechanisms are complex intracellular processes that include intracellular LPL degradation by lysosomes [53]. More specifically, it has been documented that $80 \%$ of newly synthesized LPL can be degraded in adipocytes incubated under basal conditions [53-55]. Obviously, all of these issues may have contributed to the lack of a correlation between adipose tissue LPL mRNA content and LPL activity and mass. On the other hand, although we are unsure as to why either adipose tissue LPL mass or activity did not correlate with adipose tissue mRNA content, it should be emphasized that adipose tissue mRNA content was highly correlated with degree of insulin resistance, both fasting insulin and TG concentrations, as well as with post-heparin plasma the number of LPL molecules in plasma. Thus, adipose tissue concentration of mRNA was clearly related to the whole body physiological variables we measured. While one insulin resistant subject had a mild hypertension (161/ $90 \mathrm{~mm} \mathrm{Hg}$ ), his data were not different from the other insulin resistant individuals studied in this protocol.

In conclusion, the results presented provide further support for the view that plasma TG concentrations in non-diabetic individuals are directly associated to degree of insulin resistance and inversely with plasma PH-LPL activity $[6,10,11,56-58]$. In addition to providing further evidence that resistance to insulin-mediated glucose disposal in non-diabetic individuals is associated with a decrease in plasma $\mathrm{PH}$ LPL activity, the current results show that the changes in plasma PH-LPL mass paralleled those in activity. Since adipose tissue mRNA content was also inversely correlated with degree of insulin resistance, it is proposed that the ability of insulin to stimulate the transcription of the LPL gene or to maintain the cytoplasmic LPL mRNA levels is impaired in the insulin resistant individuals, and contributes to the decrease in plasma PH-LPL activity and mass seen in this situation. Finally, irrespective of the mechanism 
involved, the results indicate that there are parallel defects in the ability of insulin to modulate glucose disposal and regulate LPL function.

A cknowledgements. Supported by grants from the National Institute of Health (HL-08506, RR-00070 and DK 39176) and by the Office of Research and Development, Medical Research Service, Department of Veterans Affairs. Dr. Maheux was a Scholar of the Medical Research Council of Canada. Dr. Salman Azhar is a Research Scientist at the VA Palo Alto Health Care System. We thank Dr. John Ong for his technical assistance in assessing the LPL mass. The support of the GCRC staff and our editorial assistants are also acknowledged.

\section{References}

1. Eckel RH (1989) Lipoprotein lipase: A multifunctional enzyme relevant to common metabolic diseases. N Engl J Med 320: 1060-1068 [published erratum in N Engl J Med 322: 477, 1990]

2. Bagdade JD, Porte D Jr, Bierman EL (1967) Diabetic lipemia. A form of acquired fat-induced lipemia. N Engl J Med 276: 427-433

3. Taylor KG, Galton DJ, Holdsworth G (1979) Insulin independent diabetes: a defect in the activity of lipoprotein lipase in adipose tissue. Diabetologia 6: 313-317

4. Taskinen M-R, Nikkilä EA (1979) Lipoprotein lipase activity of adipose tissue and skeletal muscle in insulin-deficient human diabetes. Relation to high-density and very-lowdensity lipoprotein and response to treatment. Diabetologia 17: $351-357$

5. Eckel RH, Yost TJ, Jensen DR (1995) Alterations in lipoprotein lipase in insulin resistance. Int J Obesity 19 [Suppl 1]:516-521

6. Reaven GM (1988) Role of insulin resistance in human disease. Diabetes 37: 1595-1607

7. DeFronzo RA (1988) Lilly Lecture 1987. The triumvirate: $\beta$-cell, muscle, liver: a collusion responsible for NIDDM. Diabetes 37: 667-687

8. Brunzell JD, Porte D Jr, Bierman EL (1975) Reversible abnormalities in post-heparin lipolytic activity during the late phase of release in diabetes mellitus. Metabolism 24: 11231138

9. Pykalisto O, Smith PH, Brunzell JD (1975) Determinants of human adipose tissue lipoprotein lipase. Effect of diabetes and obesity on basal- and diet-induced activity. J Clin Invest 56: 1108-1116

10. Chen Y-DI, Facchini F, Landau C, Hollenbeck CB, Reaven GM (1994) Plasma post-heparin lipoprotein lipase activity is decreased in normal individuals who are resistant to insulin-mediated glucose uptake. Endocrinol Metab 1: 153158

11. Knudsen P, Eriksson J, Lahdenperä S et al. (1995) Changes of lipolytic enzymes cluster with insulin resistance syndrome. Diabetologia 38: 344-350

12. Pollare T, Vessby B, Lithell H (1991) Lipoprotein lipase activity in skeletal muscle is related to insulin sensitivity. Arterioscler Thromb 11: 1192-1203

13. Kiens B, Lithell H, Mikines KJ, Richter EA (1989) Effects of insulin and exercise on muscle lipoprotein lipase activity in man and its relation to insulin action. J Clin Invest 84: 1124-1129

14. Sadur CN, Yost TJ, Eckel RH (1984) Insulin responsiveness of adipose tissue lipoprotein lipase is delayed but preserved in obesity. J Clin Endocrinol Metabol 59: 1176-1182
15. Potts JL, Coppack SW, Fisher RM, Humphreys SM, Gibbons GF, Frayn KN (1995) Impaired postprandial clearance of triacylglycerol-rich lipoproteins in adipose tissue in obese subjects. Am J Physiol 268:E588-E594

16. National Diabetes Data Group (1979) Classification and diagnosis of diabetes mellitus and other categories of glucose intolerance. Diabetes 28: 1039-1057

17. Hales CN, Randle PJ (1963) Immunoassay of insulin and insulin-antibody precipitate. Biochem J 88: 137-146

18. Wahlefeld AW (1974) Triglycerides. Determination after enzymatic hydrolysis. In: Bergmeyer HU (ed) Methods of enzymatic analysis. Academic Press, New York 11: 18311835

19. Shen D-C, Shieh S-M, Fuh M, Wu D-A, Chen Y-DI, Reaven GM (1988) Resistance to insulin-stimulated glucose uptake in patients with hypertension. J Clin Endocrinol Metab 66: 580-583

20. Boberg J, Carlson LA (1964) Determination of heparin-induced lipoprotein lipase activity in human plasma. Clin Chim Acta 10: 420-427

21. Nilsson-Ehle P, Schotz MC (1976) A stable, radioactive substrate emulsion for assay of lipoprotein lipase. J Lipid Res 17: 536-541

22. Belfrage P, Vaughan M (1969) Simple liquid-liquid partition system for isolation of labeled oleic acid from mixtures with glycerides. J Lipid Res 10: 341-344

23. Nilsson-Ehle P, Ekman R (1977) Rapid, simple and specific assays for lipoprotein lipase and hepatic lipase. Artery 3: 194-209

24. Iverius PH, Brunzell JD (1985) Human adipose tissue lipoprotein lipase: changes with feeding and relation to postheparin plasma enzyme. Am J Physiol 249:E107E114

25. Kern PA, Ong JM, Goers JF, Pedersen ME (1988) Regulation of lipoprotein lipase immunoreactive mass in isolated human adipocytes. J Clin Invest 81: 398-406

26. Goers JWF, Pederson ME, Kern PA, Ong J, Schotz MC (1987) An enzyme-linked immunoassay for lipoprotein lipase. Anal Biochem 166: 27-35

27. Kern PA, Martin RA, Carty J, Goldberg IJ, Ong JM (1990) Identification of lipoprotein lipase immunoreactive protein in pre- and postheparin plasma from normal subjects and patients with type I hyperlipoproteinemia. J Lipid Res 31: $17-26$

28. Pape ME, Melchior GW, Marotti KR (1991) mRNA quantification by a simple and sensitive RNAse protection assay. Gen Analysis Tech Appl 8: 206-213

29. Sanger F, Niklen S, Coulston AR (1977) DNA sequencing with chain-terminating inhibitors. Proc Natl Acad Sci USA 74: 5463-5467

30. Chomczynski P, Sacchi N (1987) Single-step method of RNA isolation by acid guanidium thiocyanate-phenolchloroform extraction. Analyt Biochem 162: 156-159

31. Louveau I, Chaudhuri S, Etherton TD (1991) An improved method for isolating RNA from porcine adipose tissue. Analyt Biochem 196: 308-310

32. Frayn KN, Langin D, Holm C, Belfrage P (1993) Hormonesensitive lipase: quantitation of enzyme activity and mRNA level in small biopsies of human adipose tissue. Clin Chim Acta 216: 183-189

33. Reaven E, Tsai L, Spicher M et al. (1994) Enhanced expression of granulosa and low density lipoprotein receptor activity in response to in vitro culture conditions. J Cell Physiol 161: 449-462

34. Suissa M (1983) Spectrophotometric quantification of silver grains eluted from autoradiograms. Analyt Biochem 133: 511-514 
35. Messina JL, Weinstock RS (1992) Regulation of $\beta$-actin gene transcription by insulin and phorbol esters. Exp Cell Res 200: 532-535

36. Solomon SS, Palazzolo MR, Elam MB, Green S, Raghow R (1994) Regulation of calmodulin gene expression by insulin is both transcriptional and post-transcriptional. J Lab Clin Med 124: 348-358

37. Myers RH (1986) Classical and modern regression with applications. Duxbury, Boston

38. Reaven GM (1994) Syndrome X: 6 years later. J Int Med 236: $13-22$

39. Babirak SP, Brown BG, Brunzell JD (1992) Familial combined hyperlipidemia and abnormal lipoprotein lipase. Arterioscler Thromb 12: 1176-1183

40. Sheu WH-H, Shieh S-M, Fuh MM-T, Shen DD-C, Jeng CY, Chen Y-DI, Reaven GM (1993) Insulin resistance, glucose intolerance, and hyperinsulinemia. Hypertriglyceridemia versus hypercholesterolemia. Arterioscler Thromb 13: $367-370$

41. Borensztajn J, Samols DR, Rubenstein AH (1972) Effects of insulin on lipoprotein lipase activity in the rat heart and adipose tissue. Am J Physiol 223: 1271-1275

42. Semenkovich CF, Wims M, Noe L, Etienne J, Chan L (1989) Insulin regulation of lipoprotein lipase activity in 3T3-L1 adipocytes is mediated at posttranscriptional and posttranslational levels. J Biol Chem 264: 9030-9038

43. Doolittle MH, Ben-Zeev O, Elovson J, Martin D, Kirchgessner TG (1990) The response of lipoprotein lipase to feeding and fasting. J Biol Chem 265: 4570-4577

44. Sadur CN, Eckel RH (1982) Insulin stimulation of adipose tissue lipoprotein lipase. Use of the euglycemic clamp technique. J Clin Invest 69: 1119-1125

45. Farese RV Jr, Trudy JY, Eckel RH (1991) Tissue-specific regulation of lipoprotein lipase activity by insulin/glucose in normal-weight humans. Metabolism 40: 214-218

46. Pei D, Chen Y-DI, Hollenbeck CB, Bhargava R, Reaven GM (1995) Relationship between insulin-mediated glucose disposal by muscle and adipose tissue lipolysis in healthy volunteers. J Clin Endocrinol Metab 80: 3368-3372

47. Coppack SW, Yost TJ, Fisher RM, Eckel RH, Miles JM (1996) Periprandial systemic and regional lipase activity in normal humans. Am J Physiol 270:E718-722
48. Beisiegel U, Krapp A, Weber W, Olivecrona G (1994) The role of $\alpha_{2} \mathrm{M}$ receptor/LRP in chylomicron remnant metabolism. Ann NY Acad Sci 737: 53-69

49. Taskinen M-R (1987) Lipoprotein lipase in hypertriglyceridemias. In: Borensztajn J (ed) Lipoprotein lipase. Evener Publishers, Inc. Chicago, pp 201-228

50. Simsolo RB, Ong JM, Kern PA (1992) Characterization of lipoprotein lipase activity, secretion, and degradation at different sites of post-translational processing in primary cultures of rat adipocytes. J Lipid Res 33: 1777-1784

51. Erskine JM, Jensen DR, Eckel RH (1994) Macronutrient regulation of lipoprotein lipase is posttranslational. J Nutr 124: 500-507

52. Ong JM, Kern PA (1989) Effect of feeding and obesity on lipoprotein lipase activity, immunoreactive protein, and messenger RNA levels in human adipose tissue. J Clin Invest 84: 305-311

53. Braun JEA, Severson DL (1992) Regulation of the synthesis, processing and translocation of lipoprotein lipase. Biochem J 287: 337-347

54. Cupp M, Bensadoun A, Melford K (1987) Heparin decreases the degradation rate of lipoprotein lipase in adipocytes. J Biol Chem 262: 6383-6388

55. Vannier C, Ailhaud G (1989) Biosynthesis of lipoprotein lipase in cultured adipocytes. II. Processing, subunit assembly, and intracellular transport. J Biol Chem 264: 13206-13216

56. Reaven GM, Lerner RL, Stern MP, Farquhar JW (1967) Role of insulin in endogenous hypertriglyceridemia. J Clin Invest 46: 1756-1767

57. Olefsky JM, Farquhar JW, Reaven GM (1974) Reappraisal of the role of insulin in hypertriglyceridemia. Am J Med 57: 551-560

58. Tobey TA, Greenfield M, Kraemer F, Reaven GM (1981) Relationship between insulin resistance, insulin secretion, very low density lipoprotein kinetics and plasma triglyceride levels in normotriglyceridemic man. Metabolism 30: 165-171 